\title{
New formula to objectively evaluate skeletal maturation using lateral cephalometric radiographs
}

\author{
Nova fórmula para avaliação objetiva da \\ maturação esquelética em radiografias \\ cefalométricas laterais
}

\begin{abstract}
Maria de Paula Caldas ${ }^{(a)}$
Gláucia Maria Bovi Ambrosano(b) Francisco Haiter Neto(c)
\end{abstract}

(a) DDS, Resident, Division of Oral Diagnosis; (b) AGR ENG, PhD, Professor, Department of Community Dentistry; (c) PhD, Professor, Division of Oral Diagnosis - School of Dentistry of Piracicaba, State University of Campinas.

\author{
Corresponding author: \\ Francisco Haiter Neto \\ Av. Limeira, 901 \\ Piracicaba - São Paulo - Brazil \\ CEP: 13414-900 \\ E-mail: haiter@fop.unicamp.br
}

Received for publication on Oct 03, 2006 Sent for alterations on Dec 01, 2006 Accepted for publication on Jan 22, 2007

\begin{abstract}
The aim of this study was to establish two new formulas for objectively evaluating skeletal maturation of cervical vertebrae in female and male Brazilian subjects using lateral cephalometric radiographs. The sample included 128 girls and 110 boys, aged 7.0 to 15.9 years, from the files of the Oral Radiology Clinic, Piracicaba Dental School, University of Campinas (Unicamp), SP, Brazil. The cervical vertebral bodies of C3 and C4 were traced and measured and regression formulas were developed in order to determine cervical vertebral bone age. Another sample of lateral teleradiographs and hand-wrist radiographs of 55 girls and 54 boys (aged 7.0 to 15.9 years) was used to verify the reliability of the developed regression formulas, as compared with bone age assessed using the Tanner et al. ${ }^{15}$ (2001) Method (TW3) in hand-wrist radiographs. The analysis of both the boys' and girls' data (ANOVA) showed no statistical difference between cervical vertebral bone age, bone age, and chronological age, indicating that these formulas can be used in this population ( $\mathrm{p}=0.5721$ and $\mathrm{p}=0.6007$ for girls and boys, respectively). Female cervical vertebral bodies of C3 and C4 increased in an accelerated manner from 10 to 13 years. Analysis of the male sample showed that C3 measurements increased in an accelerated manner from 12 to 15 years. The C4 measurements, however, did not increase at all. Using cervical vertebral bone age it is possible to evaluate skeletal maturation objectively in cephalometric radiographs.
\end{abstract}

Descriptors: Puberty; Cervical vertebrae; Growth; Measures.

Resumo: O objetivo deste estudo foi estabelecer dois novos métodos para meninas e meninos brasileiros, no intuito de determinar de forma objetiva a maturação esquelética das vértebras cervicais em radiografias cefalométricas laterais. Foram selecionados 128 meninas e 110 meninos, com faixa etária variando entre 7 e 15,9 anos, pertencentes à Clínica de Radiologia da Faculdade de Odontologia de Piracicaba da Universidade de Campinas (Unicamp). Os corpos da terceira e quarta vértebras cervicais foram traçados e medidos e fórmulas de regressão foram criadas no intuito de se estabelecer a idade óssea das vértebras cervicais. Uma outra amostra composta por telerradiografias em normal lateral e radiografias carpais de 55 meninas e 54 meninos com a mesma faixa etária foi utilizada para verificar a confiabilidade das fórmulas criadas, em comparação à idade óssea determinada pelo método de Tanner et al..$^{15}$ (2001) (TW3) em radiografias carpais. A análise da amostra feminina e masculina (ANOVA) revelou não haver diferença estatística significativa entre idade óssea da vértebra cervical, idade esquelética e idade cronológica, indicando que as fórmulas desenvolvidas podem ser utilizadas nesta população ( $p=0,5721$ e $\mathrm{p}=0,6007$ para meninas e meninos, respectivamente). Os corpos da terceira e quarta vértebras cervicais aumentaram de forma acelerada dos 10 aos 13 anos nas meninas. A análise da amostra masculina revelou aumento acelerado de C3 dos 12 aos 15 anos. A vértebra C4, no entanto, não aumentou em tamanho. Utilizando a idade óssea de vértebras cervicais, é possível avaliar a maturidade esquelética de forma objetiva em radiografias cefalométricas laterais.

Descritores: Puberdade; Vértebras cervicais; Crescimento; Medidas. 


\section{Introduction}

Determination of maturation and subsequent evaluation of growth potential during pre-adolescence or adolescence is extremely important. Growth stages can be identified by chronological age, sexual maturation characteristics, dental development, body height, weight, and skeletal development. ${ }^{3,5,13}$ However, chronological age by itself cannot be used for identifying the stages of developmental progression. $^{2}$

Because of individual variations in timing, duration and velocity of growth, skeletal age assessment is essential for designing orthodontic treatment plans. ${ }^{7}$ Hand-wrist radiographs have been used for determination of maturation and subsequent evaluation of growth potential. However, a more reliable and objective method that does not require radiographs is needed to reduce X-ray exposure as much as possible.

Cervical vertebrae appear on cephalometric radiographs, which are usually used by orthodontists to plan treatment. It is known that the morphology of the cervical vertebral bodies changes with growth, as seen on lateral cephalograms. ${ }^{12,16}$ Lamparski ${ }^{9}$ (1972) published a method that simulated morphological changes in cervical vertebral bodies and found them to be as reliable and as valid as the hand-wrist area for assessing skeletal age. The effectiveness of the cervical vertebrae as a maturational indicator has been corroborated by Hassel, Farman ${ }^{7}$ (1995) and Garcia-Fernandes et al. ${ }^{4}$ (1998), who found a high correlation between cervical vertebral maturation and the skeletal maturation of the handwrist area. The limitation inherent to Lamparski's method, though, is that it cannot be used to evaluate growth in an objective manner.

Mito et al. ${ }^{10}$ (2002) reported that cervical vertebral bone age can be calculated based on cephalometric radiographs. They measured cervical vertebral bodies and determined a formula to obtain skeletal age. However, the sample used to derive the formula consisted of Japanese people.

The purpose of this study was to establish two new formulas to objectively evaluate skeletal maturation in female and male Brazilian subjects using cephalometric radiographs.

\section{Material and Methods}

Lateral cephalometric and hand-wrist radiographs obtained from the files of the Oral Radiology Clinic, Piracicaba Dental School, State University of Campinas, São Paulo, SP, Brazil, were examined. Group 1 was composed of 238 subjects (128 girls and 110 boys), aged 7.0 to 15.9 years. This group was used to derive two different formulas for obtaining cervical vertebral bone age in female and male subjects. A different sample (Group 2) consisting of 55 girls and 54 boys (aged 7.0 to 15.9 years) was used to verify the reliability of the newly developed regression formula, as compared with the bone age data assessed by the Tanner et al. ${ }^{15}$ (2001) method (TW3) in hand-wrist radiographs. Ethical approval to conduct this study was granted from the Piracicaba Dental School Committee and the patients signed an informed consent form prior to participating.

All cephalometric radiographs were used in group 1 to calculate cervical vertebral bone age, which were traced by hand on mate acetate film (Converflex Ltda., Lordelo, Guimarães, Portugal) and measured with micrometer calipers (Acrimet Ind. e Com. Ltda., São Paulo, SP, Brazil) by the same operator. The measurements made were anterior vertebral body height $(\mathrm{AH})$, vertebral body height $(\mathrm{H})$, posterior vertebral body height $(\mathrm{PH})$, and anteroposterior vertebral body length (AP) on the third and fourth cervical vertebrae (Figure 1).

Bone age was evaluated by the TW3 method, which assessed specific ossification centers of the hand and wrist (radius, ulna, and selected metacarpals and phalanges), leading to their classifications into one of several stages; scores were derived from each bone stage and calculated to compute the skeletal age. The hand-wrist radiographs were used as gold standard to determine the reliability of the formulas developed to assess cervical vertebral bone age.

Intra-operator error was calculated according to Dahlberg's formula using ten cephalometric radiographs selected randomly from group 1; these were traced and measured with micrometer calipers, and the same radiographs were measured again ten days later. The formula revealed values below 1.0, indicating sufficient accuracy of the measurements and implying a high degree of reliability. 


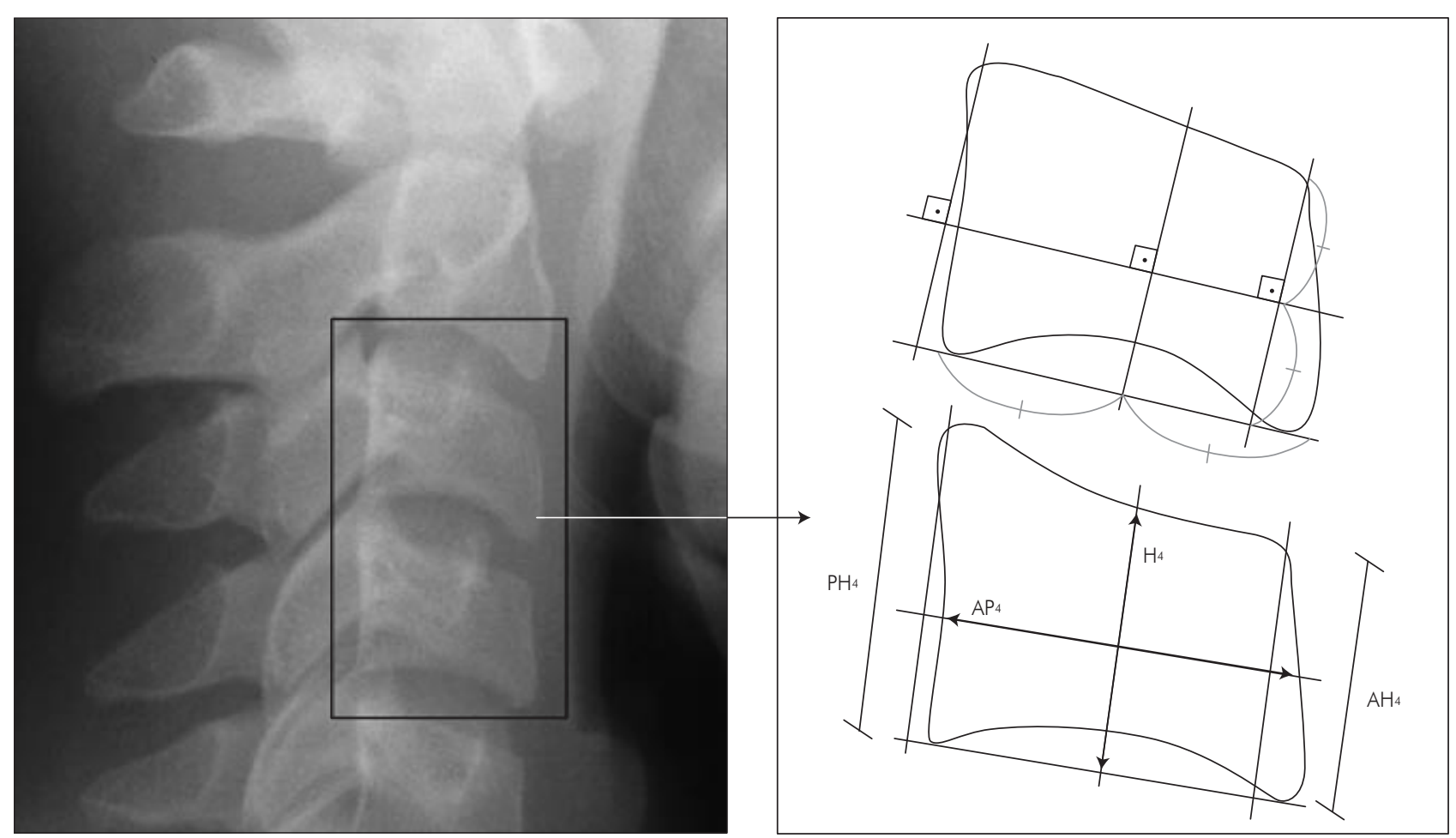

Figure 1 - Cervical vertebral bodies measured on cephalometric radiographs: anterior vertebral body height (AH), vertebral body height $(\mathrm{H})$, posterior vertebral body height $(\mathrm{PH})$, and anteroposterior vertebral body length (AP) of the third and fourth cervical vertebrae.

A stepwise multiple regression analysis was used for determining the formulas to obtain cervical vertebral bone age using bone age as dependent variable and the ratios $(\mathrm{AH}, \mathrm{H}, \mathrm{PH}, \mathrm{AP})$ as independent variables. Adequacy of the model was evaluated by Mallows Cp statistics.

Analysis of variance (ANOVA) was used to determine if there was a statistically significant difference between cervical vertebral bone age, bone age, and chronological age. All analysis were performed with SAS (SAS Inc., Cary, North Carolina, USA) and with a significance level of $5 \%$.

\section{Results}

Parameters were measured on the third and fourth cervical vertebrae (Graphs 1, 2, 3 and 4) of both females' and males' cephalometric radiographs. When analyzing the female sample, $\mathrm{AH}_{3}$, $\mathrm{PH}_{3}, \mathrm{H}_{3}$ increased in an accelerated manner from 10 to 13 years. $\mathrm{AH}_{4}, \mathrm{PH}_{4}$ and $\mathrm{H}_{4}$ increased in an accelerated manner from 11 to 13 years. Analysis of the male sample showed that $\mathrm{AH}_{3}, \mathrm{AP}_{3}, \mathrm{PH}_{3}$, and
$\mathrm{H}_{3}$ increased in an accelerated manner from 12 to 15 years. On the other hand, $\mathrm{AH}_{4}, \mathrm{AP}_{4}, \mathrm{PH}_{4}$ and $\mathrm{H}_{4}$ did not increase at all. A stepwise multiple regression analysis was developed in order to determine the formulas to obtain cervical vertebral bone age:

- Female cervical vertebral bone age $=1.3523+$ $6.7691 \times \mathrm{AH}_{3} / \mathrm{AP}_{3}+8.6408 \times \mathrm{AH}_{4} / \mathrm{AP}_{4}$

- Male cervical vertebral bone age $=1.4892+$ $11.3736 \times \mathrm{AH}_{3} / \mathrm{AP}_{3}+4.8726 \times \mathrm{H}_{4} / \mathrm{AP}_{4}$

Cervical vertebral bone age, bone age, and chronological age in group 2 were calculated in order to determine the reliability of the formulas. The analysis of both boys' and girls' data showed no statistically significant difference between cervical vertebral bone age, bone age, and chronological age, indicating that these formulas can be used in Brazilians (Tables 1 and 2).

\section{Discussion}

The use of skeletal age has been shown to be more reliable and accurate than the use of chronological age in assessing an individual's progress toward ma- 


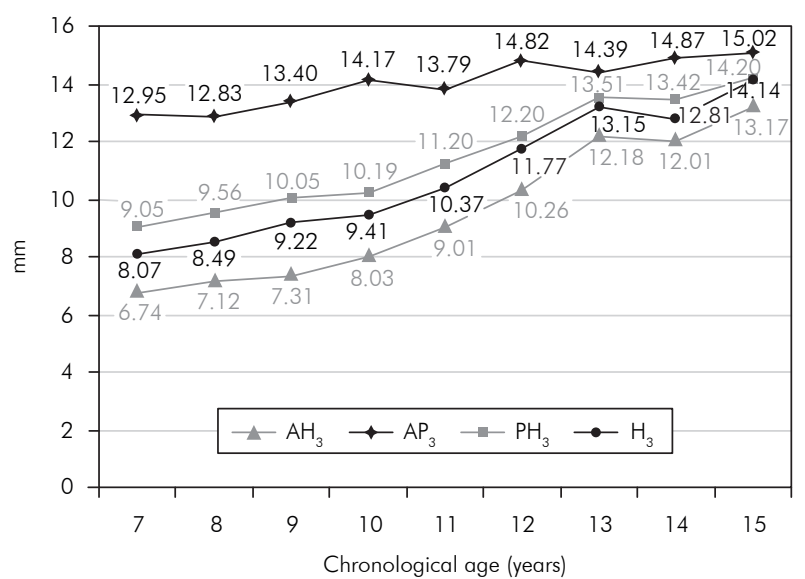

Graph 1 - Average change in each part of the third cervical vertebral body in females (group 1).

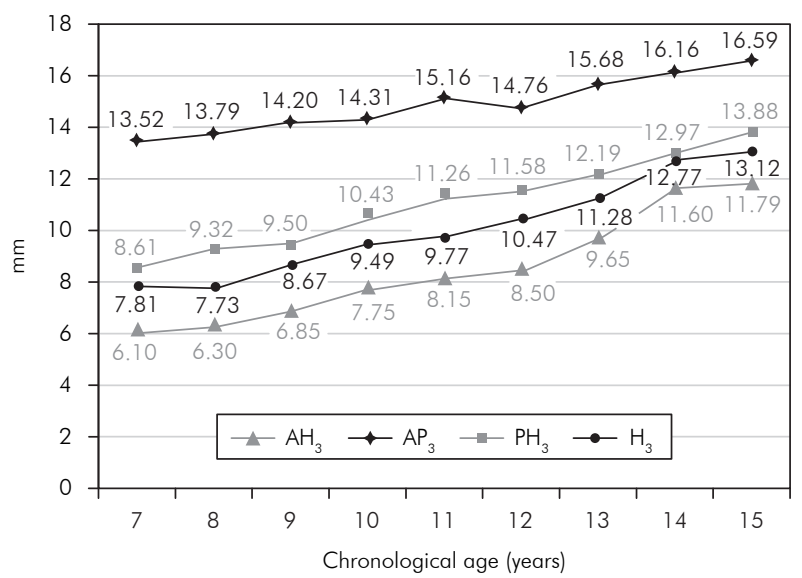

Graph 3 - Average change in each part of the third cervical vertebral body in males (group 1).

Table 1 - Mean (years) and standard deviation (SD) of cervical vertebral bone age (CVBA), bone age (BA) and chronological age (CA) for the girls' sample.

\begin{tabular}{l|c|c}
\multicolumn{1}{c|}{ Group } & Mean & SD \\
\hline CVBA & 10.57856 & 2.18149 \\
\hline BA & 10.41636 & 2.93302 \\
\hline CA & 10.40072 & 2.57364 \\
\hline
\end{tabular}

$p=0.5721$.

turity. ${ }^{11}$ In recent years, evaluation of cervical vertebrae has been increasingly used to determine skeletal maturation. Almost all previous evaluations with cervical vertebrae on cephalometric radiographs used the method reported by Lamparski ${ }^{9}$ (1972). This method takes into account morphological char-

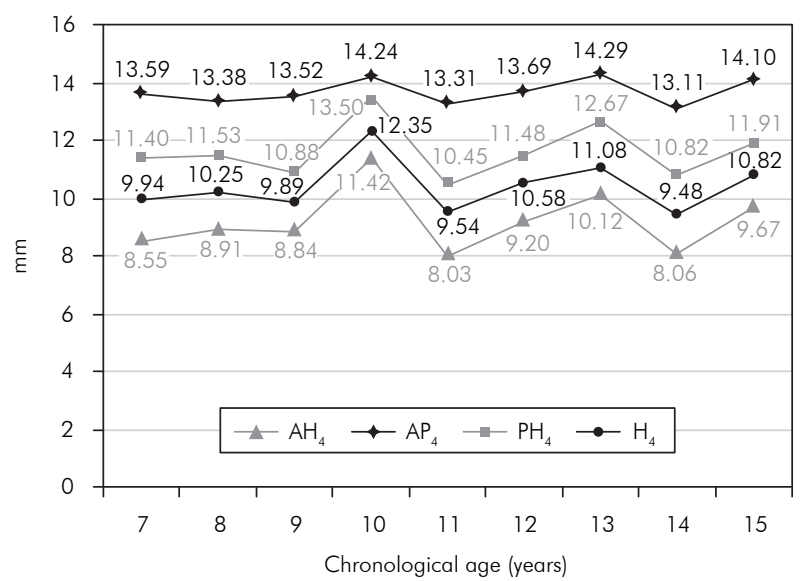

Graph 2 - Average change in each part of the fourth cervical vertebral body in females (group 1).

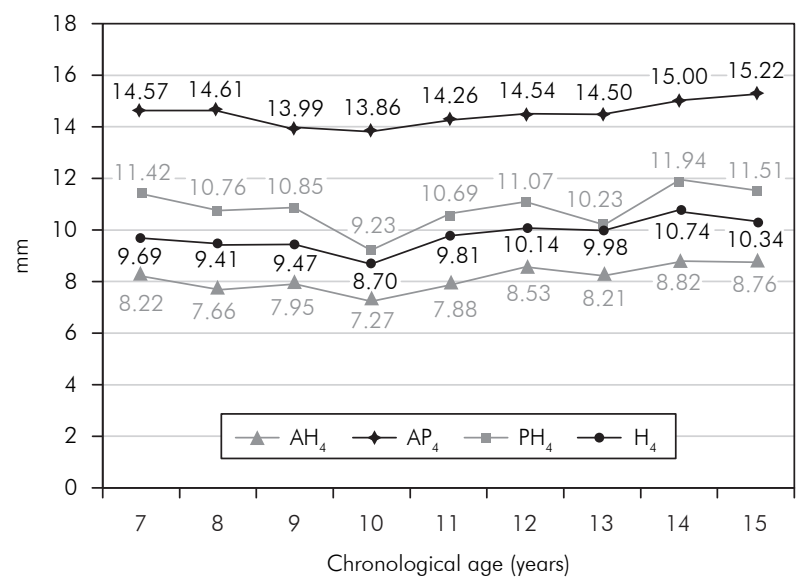

Graph 4 - Average change in each part of the fourth cervical vertebral body in males (group 1).

Table 2 - Mean (years) and standard deviation (SD) of cervical vertebral bone age (CVBA), bone age (BA) and chronological age (CA) for the boys' sample.

\begin{tabular}{l|c|c}
\hline \multicolumn{1}{c|}{ Group } & Mean & SD \\
\hline CVBA & 10.77162 & 1.71684 \\
\hline BA & 10.60240 & 2.45301 \\
\hline CA & 10.57129 & 2.61778 \\
\hline
\end{tabular}

$p=0.6007$

acteristics of the cervical vertebrae, as concavity of the lower border and height and shape of the vertebral bodies. However, cervical vertebrae are used to evaluate growth in a subjective manner, because the method uses only a qualitative comparison between the patient's images and those of an atlas. Thus, the 
method developed in the present study may be of great importance because it allows skeletal age to be calculated in an objective manner.

Mito et al. ${ }^{10}$ (2002) established a formula for objectively evaluating skeletal maturation on cephalometric radiographs. They examined only Japanese girls because of sex-dependent differences with regard to the timing of morphological changes in cervical vertebral bodies. ${ }^{14}$ However, when the formula was applied to a different population of children developing under different environmental circumstances, we found that the method developed could be applied only to Brazilian women. In the present study, the sample selected was composed by both female and male subjects in order to establish two different formulas to objectively evaluate skeletal maturation using cephalometric radiographs.

We measured cervical vertebral bodies because many investigators have suggested that the size and shape of the cervical vertebrae change from birth to full maturity at each level of skeletal development. ${ }^{8}$ We selected the third and fourth vertebral bodies because the cervical vertebrae lower than C4 cannot be observed when a thyroid protective collar is worn during radiation exposure. Baccetti et al. ${ }^{1}$ (2002) showed that only the shape change of $\mathrm{C} 2, \mathrm{C} 3$, and $\mathrm{C} 4$ was enough to show skeletal maturation. However, C2 is very difficult to measure and it shows little morphological change. In the present study, we measured only C3 and C4.

Hägg, Taranger ${ }^{6}$ (1980) reported that the pubertal growth spurt begins at the age of 10 years in girls and at the age of 12 years in boys. In both genders, the growth peak occurs two years after the spurt begins and then the growth goes on up to the ages of

\section{References}

1. Baccetti T, Franchi L, McNamara Jr JA. An improved version of the cervical vertebral maturation (CVM) method for the assessment of mandibular growth. Angle Orthod. 2002;72(4):316-23.

2. Fishman LS. Chronological versus skeletal age, an evaluation of craniofacial growth. Angle Orthod. 1979;49(3):181-9.

3. Fishman LS. Maturational patterns and prediction during adolescence. Angle Orthod. 1987;57(3):178-93.
15 and 17 years in girls and boys, respectively. In the present study, analysis of the female sample showed that $\mathrm{AH}_{3}, \mathrm{PH}_{3}, \mathrm{H}_{3}$ increased in an accelerated manner from 10 to 13 years. $\mathrm{AH}_{4}, \mathrm{PH}_{4}$ and $\mathrm{H}_{4}$ increased in an accelerated manner from 11 to 13 years. Analysis of the male sample showed that $\mathrm{AH}_{3}, \mathrm{AP}_{3}, \mathrm{PH}_{3}$, and $\mathrm{H}_{3}$ increased in an accelerated manner from 12 to 15 years of age. The data for $\mathrm{AH}_{4}, \mathrm{AP}_{4}, \mathrm{PH}_{4}$ and $\mathrm{H}_{4}$ did not increase at all. The lack of growth in $\mathrm{C} 4$ could be explained by the fact that maturational changes occur in cervical vertebrae at different times. Concavity of the lower border of the vertebrae appears sequentially from $\mathrm{C} 2$ to $\mathrm{C} 6$. The differences in the skeletal age assessments according to time of observation between female and male subjects were expected since girls reach skeletal maturity before boys do.

When determining the reliability of the formulas, both female and male subjects showed no statistically significant difference between cervical vertebral bone age, bone age, and chronological age, indicating that the formulas can be applied to Brazilians. The establishment of an objective method to evaluate skeletal maturation in this population using cephalometric radiographs might contribute to a better orthodontic diagnosis and treatment plann for growing children.

\section{Conclusions}

The results suggest that the method established in the present study for objectively evaluating skeletal maturation in cephalometric radiographs is reliable and can be applied to both female and male subjects. A computer software to automatically calculate cervical vertebral bone age is needed to increase objectivity.

4. Garcia-Fernandes P, Torre H, Flores L, Rea J. The cervical vertebrae as maturational indicators. J Clin Orthod. 1998;32(4):221-5.

5. Hägg U, Taranger J. Maturation indicators and the pubertal growth spurt. Am J Orthod. 1982;82(4):299-309.

6. Hägg U, Taranger J. Skeletal stages of the hand and wrist as indicators of the pubertal growth spurt. Acta Odontol Scand. 1980;38(3):187-200. 
7. Hassel B, Farman AG. Skeletal maturation evaluation using cervical vertebrae. Am J Orthod Dentofacial Orthop. 1995;107(1):58-66.

8. Kucukkeles N, Acar A, Biren S, Arun T. Comparisons between cervical vertebrae and hand-wrist maturation for the assessment of skeletal maturity. J Clin Pediatr Dent. 1999;24(1):4752.

9. Lamparski DG. Skeletal age assessment utilizing cervical vertebrae [Dissertation]. Pittsburgh: University of Pittsburgh; 1972.

10. Mito T, Sato K, Mitani H. Cervical vertebral bone age in girls. Am J Orthod Dentofacial Orthop. 2002;122(4):380-5.

11. Moed G, Wight BW, Vandegrift HN. Studies of physical disability: reliability of measurement of skeletal age from hand films. Child Dev. 1962;33:37-41.
12. Remes VM, Heinanen MT, Kinnunen JS, Marttinen EJ. Reference values for radiological evaluation of cervical vertebral body shape and spinal canal. Pediatr Radiol. 2000;30(3):190-5.

13. Singer J. Physiologic timing of orthodontic treatment. Angle Orthod. 1980;50(4):322-33.

14. Singh GD, McNamara JA Jr, Lozanoff S. Procrustes, Euclidean and cephalometric analyses of the morphology of the mandible in human Class III malocclusions. Arch Oral Biol. 1998;43(7):535-43.

15. Tanner JM, Whitehouse RH, Cameron N, Marshall WA, Healy MJR, Goldstein NH. Assessment of skeletal maturity and prediction of adult height (TW3 method). $3^{\text {rd }}$ ed. London: W.B. Saunders; 2001.

16. Taylor JR. Growth of human intervertebral discs and vertebral bodies. J Anat. 1975;120(Pt 1):49-68. 